ISSN 1991-8631

Short Communication

http://indexmedicus.afro.who.int

\title{
Microbial survey of fish ponds and mineral composition of Clarias gariepinus in Ilorin metropolis
}

\author{
C.G. NZEH ${ }^{1^{*}}$ and A.O. UDEZE ${ }^{2}$ \\ ${ }^{l}$ Department of Zoology, University of Ilorin, Ilorin, Nigeria. \\ ${ }^{2}$ Department of Microbiology, University of Ilorin, Ilorin, Nigeria. \\ *Corresponding author, E-mail: cgnzeh@yahoo.com
}

\begin{abstract}
This work reports on the microbial composition of stagnant fish ponds and mineral \& metal composition of Clarias gariepinus from the fish ponds in Ilorin, Kwara State, Nigeria. The fishes apparently thrived well in the fish ponds. Microbiological analysis of the different fish ponds as well as the mineral composition of the fish samples were carried out. Results revealed bacterial counts ranging from $1.0-2.0 \times 10^{4}$ $\mathrm{cfu} / \mathrm{ml}$ of the stagnant ponds water, $9.0 \times 10^{3}-1.2 \times 10^{4} \mathrm{cfu} / \mathrm{ml}$ of water from fish ponds whose water was changed daily and $3-10 \times 10^{3} \mathrm{cfu} / \mathrm{ml}$ of water from borehole. Total coliform count ranged from $6 \times 10^{3}-1.5 \mathrm{x}$ $10^{4} \mathrm{cfu} / \mathrm{ml}$ of the stagnant pond water, $6-18 \mathrm{cfu} / 100 \mathrm{ml}$ of water from ponds whose water was changed daily and $1-6 \mathrm{cfu} / 100 \mathrm{ml}$ of water from borehole. Pathogenic fungi (Aspergillus niger) was isolated from the stagnant pond water while none was isolated from fish ponds whose water was changed daily. Faecal coliforms were not isolated from any of the water samples. Analysis of the mineral composition of the fish samples showed that phosphorus and potassium were highest in fish from ponds that the water is changed daily. Metal concentration in the fish showed that $\mathrm{Cd}, \mathrm{Pb}, \mathrm{Co}$ and $\mathrm{Cr}$ did not exceed the maximum acceptable concentration for humans. Proper cooking before consumption of fish is therefore advocated to prevent transmission of the bacteria and fungi to the consumers.
\end{abstract}

(C) 2012 International Formulae Group. All rights reserved.

Keywords: Clarias gariepinus, microbial survey, mineral composition, Ilorin, Nigeria.

\section{INTRODUCTION}

Fish is an important and the cheapest source of animal protein and account for about $37 \%$ of Nigeria's total protein requirement (FDF, 2004). It is acknowledged as the efficient means of providing food which is rich in protein source, income and employment opportunities for the populace. Catfishes of the family Claridae comprise one of the most commonly cultivated fishes in Nigeria. The production of the fish in Nigeria is however bedevilled by a lot of problems notably water pollution. Pollution of aquatic environment is a serious and growing problem. Increasing numbers and amounts of industrial, agricultural and commercial chemicals discharged into the aquatic environment have led to various deleterious effects on aquatic organisms. Of great concern also is the microbial contamination of the aquatic environment which exposes the fishes to microbial infection. The water bodies in 
which the fish live are liable to contamination with enteric bacteria. Although many members of this group of bacteria inhabit soil, water, and decaying matter, they are also common occupants of the large bowel of humans and animals. Enteric pathogens are the most frequent cause of diarrheal illnesses, which account for an annual mortality rate of 3 million people and an estimated 4 billion infections worldwide (Talaro, 2005). Most of the bacteria in the water are considered as saprophytes which can become pathogenic under certain conditions. The prevalence of infectious diseases depends on the interaction between fish pathogen and the environment (Klesius, 1992; Mqolomba \& Plumb, 1992; Boon \& Huisman, 1996; Noga, 2000). Besides, the pathogen spreading, mostly under unpredictable circumstances, can result in a sudden onset of a disease in an obviously healthy population. Nzeh and Udeze (2011) have demonstrated the pathogenicity of Lactobacillus delbruekii (an otherwise none pathogenic bacteria) under condition of high microbial load. The bacteriological examination of water has a special significance in pollution studies, as it is a direct measurement of deleterious effect of pollution on human health (APHA, 1981). Coliforms are the major microbial indicator of monitoring water quality (Brenner et al., 1993; Grant 1997). This work therefore was carried out to determine the microbial quality of some stagnant fish ponds in Ilorin metropolis and the mineral composition of Clarias gariepinus grown in them as well as borehole water and control fish ponds whose water was changed on a daily basis with a view to determining the safety of consumption of fish from the ponds.

\section{MATERIALS AND METHODS Study area}

The study was conducted in Ilorin, Kwara state, Nigeria located on longitude $4^{\circ} 30$ minutes and $4^{0} 45$ minutes $\mathrm{E}$ and latitude $8^{0} 40$ minutes $\mathrm{N}$. The study area is shown in Fig. 1.

\section{Water sampling}

Water samples were taken from four different stagnant fish ponds (samples A, B, C and D), two fish ponds whose water are changed daily (samples $\mathrm{E}$ and $\mathrm{F}$ ) and one borehole (sample G) within the Ilorin metropolis into pre-sterilized bottles and transported immediately to the laboratory for bacteriological analyses. Standard sampling guidelines and methods were followed in sample collection (WHO, 1997).

\section{Fish sampling and determination of mineral and metal concentrations}

Fish samples (Clarias gariepinus) were collected from all the fish ponds with the help of fishing nets and taken to the laboratory for analysis. The samples were dried in an oven at a temperature of $60{ }^{\circ} \mathrm{C}$. The samples were milled and $2 \mathrm{~g}$ was ashed in a furnace at a temperature of $500{ }^{0} \mathrm{C}$. The porcelain crucible was half filled with $3 \mathrm{ml}$ of $2 \mathrm{M} \mathrm{H}$ CL.The solution was transferred into $50 \mathrm{ml}$ beaker using a pipette. The extraction with $2 \mathrm{M} \mathrm{H}$ CLwas repeated 4 times. About $15 \mathrm{ml}$ of distilled water was also used to wash the sample. The mixture of the beaker was filtered into $50 \mathrm{ml}$ volumetric flask (Fawole \& Oso 2007). The sample was made up to $50 \mathrm{ml}$ by addition of distilled water.

The determination of the levels of inorganic minerals: $\mathrm{Ca}, \mathrm{Na} . \mathrm{Fe}, \mathrm{K}, \mathrm{P}$, and $\mathrm{Mg}$ \& metal:Cd,Pb,Co and Co were carried out using the atomic absorption spectrophotometer model 420 Perkin-Elmer, Norwalk, C.T. (AOAC, 1990).

\section{Microbiological analysis}

Quantitative bacteriological analysis of the water samples were carried out using total plate count on nutrient agar (NA) while fungi isolation was carried out using Potato Dextrose Agar (PDA). Total coliform and faecal coliform were detected using MacConkey agar and Eosin Methylene Blue (EMB) agars respectively. Their counts were expressed in $\mathrm{cfu} / \mathrm{ml}$.The method of Fawole and Oso 2007 was used. 


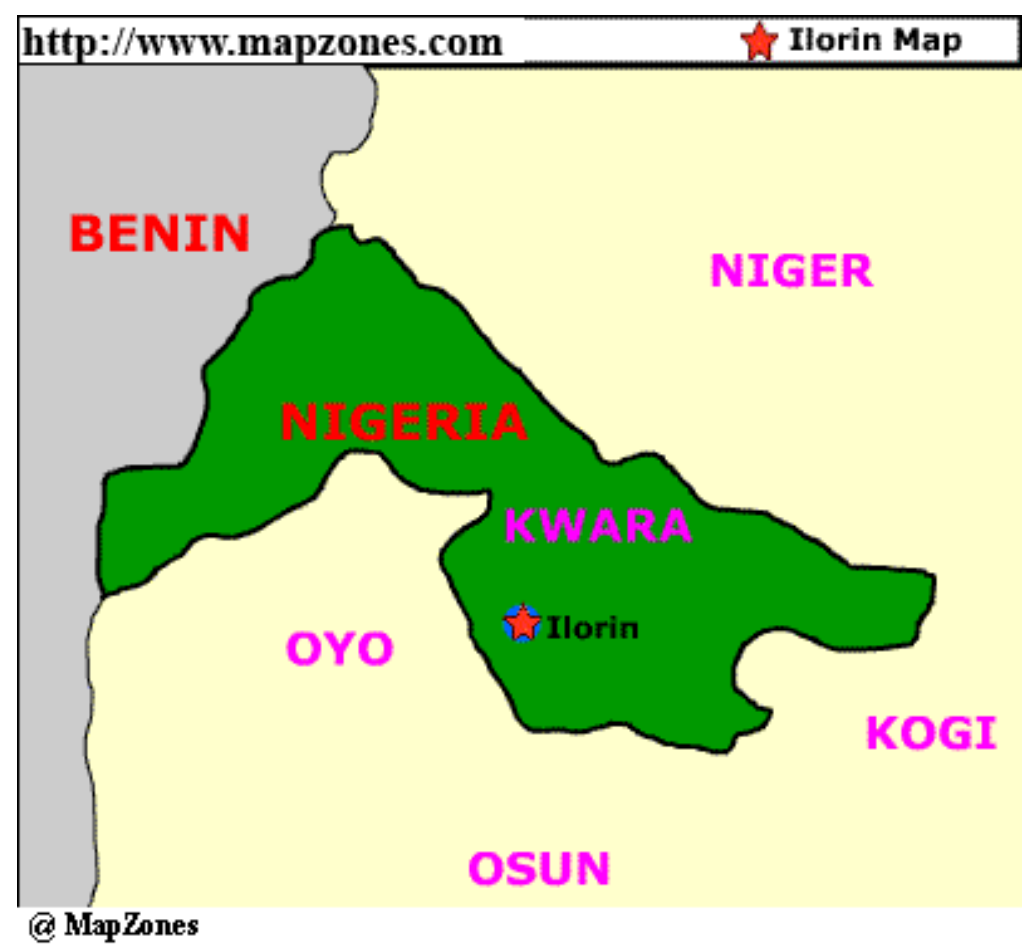

Figure 1: Map showing Ilorin metropolis.

\section{RESULTS AND DISCUSSION}

The results of the total bacterial count, total coliform count, faecal coliform count and presence of fungi in the water samples are presented in Table 1. Highest bacterial count $\left(2.0 \times 10^{4} \mathrm{cfu} / \mathrm{ml}\right)$ was observed in sample D while the least bacterial count $\left(3 \times 10^{3} \mathrm{cfu} / \mathrm{ml}\right)$ was observed in sample G. Highest coliform count $\left(1.5 \times 10^{4} \mathrm{cfu} / \mathrm{ml}\right)$ was recorded in sample D while the least count $(10 \mathrm{cfu} / \mathrm{ml})$ was recorded in sample G. Faecal coliform was not isolated from any of the water samples. Pathogenic fungi (Aspergillus niger) was isolated from all the stagnant pond water while none was isolated from fish ponds whose water were changed daily and from borehole water.

The analysis of mineral composition of the fish samples showed that $\mathrm{Ca}$ content in fishes from stagnant ponds ranged from $0.86-$ $1.81 \%$, while it was 1.66 in fishes from ponds that the water was changed regularly. $\mathrm{Mg}$ content ranged from $0.22-0.34 \%$ in fishes from stagnant ponds while it was 0.18 in fish from ponds that water was changed. $\mathrm{K}$ ranged from $0.55-0.73 \%$, the highest value was obtained from fish in ponds that water was changed. P ranged from $0.62-1.03 \%$ and $\mathrm{Fe}$ ranged from $30.52-74.96 \mathrm{mg} / \mathrm{kg}$ as shown in Table 2. Phosphorus and Potassium were highest in fish from ponds that the water was changed daily. Metal concentration (Table 3) shows that Cd was less than 0.01 , in all the fishes from sampled ponds. $\mathrm{Pb}$ was less than 0.05 , Co was less than 0.02 . $\mathrm{Cl}$ was not present in the fish examined.When waters are used for recreation or are a source of seafood that is consumed uncooked, the possibility for disease transmission exist (Wiley et al.,2008) Most of the fishes in the aquatic environment are resistant to most of the bacteria present in the water under conditions of low microbial load. However, the fishes can act as carriers of the bacteria and consumption of the fishes when not properly cooked (as practiced in some parts of the world) can lead to infection. The presence of certain bacteria like Escherichia coli and Staphylococcus aureus pose a threat to fish handlers and fish 
consumers by causing enteric diseases and also occupational disease to fish handlers.

Analysis of the water samples revealed contamination with bacteria most of which are coliforms. Further analysis however showed that faecal coliforms are absent from the water samples indicating other sources of contamination apart from faecal materials. This however rules out the possibility of invasion of the fish body by pathogenic bacteria. Strauss(1985) reported that invasion of fish flesh by pathogenic bacteria was very likely if the fish were reared in water containing over $10^{4}$ of faecal coliforms (Escherichia coli) and that high concentrations of pathogenic microorganisms might occur in the digestive tract and intraperitoneal fluid of the fish even at low numbers of indicatory bacteria.

Opportunistic mycoses may start as normal flora or ubiquitous environmental contaminants. The importance of opportunistic fungal pathogens is increasing because of the expansion of the immunocompromised patient population. The isolation of opportunistic fungi, Aspergillus niger from the water samples is a pointer to existence of organic debris which is known to support its proliferation. Hence, the consumption of the fish from the stagnant fish ponds becomes unsafe unless the fish is properly cooked. Aspergillus can cause opportunistic infection (systemic aspergillosis) in immunocompromised patients.
The results indicated that the concentration of calcium, magnesium, potassium, and phosphorus in C. gariepinus were low, Adakole and Balogun (2006) obtained higher concentration of $\mathrm{Ca}$ and $\mathrm{Mg}$ for C. gariepinus in Bindare stream and Galma River in Northern Nigeria.

The results also showed that the concentration of Iron in C. gariepinus although low in value, were within the WHO/FAO (1974) recommended values. The concentrations of phosphorus in the fishes examined were low. Post (1987) observed that phosphorus can be absorbed directly from the water, this result suggests that phosphorus content of the ponds inhabited by the fish was very low.

The concentrations of cadnium, chromium, cobalt and lead in the fish samples did not exceed the maximum acceptable concentrations of $0.002 \mathrm{mg} / \mathrm{kg}, 0.002 \mathrm{mg} / \mathrm{kg}$, $0.01 \mathrm{mg} / \mathrm{kg}$ and $0.05 \mathrm{mg} / \mathrm{kg}$ respectively indicating that there was no bioaccumulation of these metals in the fish although the water is not being changed regularly. Possible health risks as a result of the consumption of the fishes are therefore ruled out.

Iron is important for the formation of haemoglobin (Post 1987), this fish is a good source of the nutrient. This research has shown that the fishes had little $\mathrm{Pb}, \mathrm{Cr}, \mathrm{Cd}$ and Co concentrations although they inhabit stagnant ponds that the water was not changed, the fish does not constitute a health risk in terms of metal concentration.

Table 1: The microbial counts and presence of fungi in the different water samples.

\begin{tabular}{lcccc}
\hline Sample & Total bacteria count & Total coliform count & Faecal coliform count & Fungi \\
\hline $\mathrm{A}$ & $1.0 \times 10^{4} \mathrm{cfu} / \mathrm{ml}$ & $8 \times 10^{3} \mathrm{cfu} / \mathrm{ml}$ & $0 \mathrm{cfu} / \mathrm{ml}$ & + \\
$\mathrm{B}$ & $1.2 \times 10^{4} \mathrm{cfu} / \mathrm{ml}$ & $6 \times 10^{3} \mathrm{cfu} / \mathrm{ml}$ & $0 \mathrm{cfu} / \mathrm{ml}$ & + \\
$\mathrm{C}$ & $1.4 \times 10^{4} \mathrm{cfu} / \mathrm{ml}$ & $1.1 \times 10^{4} \mathrm{cfu} / \mathrm{ml}$ & $0 \mathrm{cfu} / \mathrm{ml}$ & + \\
$\mathrm{D}$ & $2.0 \times 10^{4} \mathrm{cfu} / \mathrm{ml}$ & $1.5 \times 10^{4} \mathrm{cfu} / \mathrm{ml}$ & $0 \mathrm{cfu} / \mathrm{ml}$ & + \\
$\mathrm{E}$ & $1.2 \times 10^{4} \mathrm{cfu} / \mathrm{ml}$ & $1.8 \times 10^{2} \mathrm{cfu} / \mathrm{ml}$ & $0 \mathrm{cfu} / \mathrm{ml}$ & - \\
$\mathrm{F}$ & $9 \times 10^{3} \mathrm{cfu} / \mathrm{ml}$ & $60 \mathrm{cfu} / \mathrm{ml}$ & $0 \mathrm{cfu} / \mathrm{ml}$ & - \\
$\mathrm{G}$ & $3 \times 10^{3} \mathrm{cfu} / \mathrm{ml}$ & $10 \mathrm{cfu} / \mathrm{ml}$ & $0 \mathrm{cfu} / \mathrm{ml}$ & - \\
\hline + & present; - &
\end{tabular}


Table 2: Mineral composition of Clarias gariepinus from the different water samples.

\begin{tabular}{|c|c|c|c|c|c|}
\hline \multirow[t]{2}{*}{ Sample } & \multicolumn{4}{|c|}{ Concentration (\%) } & \multirow{2}{*}{$\frac{(\mathrm{mg} / \mathrm{kg})}{\mathrm{Fe}}$} \\
\hline & $\mathbf{C a}$ & Mg & $\mathbf{K}$ & $\mathbf{P}$ & \\
\hline $\mathrm{A}$ & 0.86 & 0.22 & 0.61 & 0.89 & 25.5 \\
\hline $\mathrm{B}$ & 1.14 & 0.34 & 0.59 & 0.63 & 41.16 \\
\hline $\mathrm{C}$ & 0.87 & 0.28 & 0.61 & 0.89 & 74.96 \\
\hline $\mathrm{D}$ & 1.81 & 0.27 & 0.55 & 0.62 & 30.52 \\
\hline $\mathrm{E}$ & 1.66 & 0.18 & 0.73 & 1.03 & 30.94 \\
\hline
\end{tabular}

Table 3: Metal concentration in Clarias gariepinus from the stagnant pond water.

\begin{tabular}{lccccc}
\hline Sample & \multicolumn{5}{c}{ Concentration $(\mathbf{m g} / \mathbf{k g})$} \\
\cline { 2 - 5 } & $\mathbf{C d}$ & $\mathbf{P b}$ & $\mathbf{C o}$ & $\mathbf{C r}$ & $\mathbf{C l}^{-}$ \\
\hline $\mathrm{A}$ & $<0.01$ & $<0.05$ & $<0.02$ & $<0.02$ & Nil \\
$\mathrm{B}$ & $<0.01$ & $<0.05$ & $<0.02$ & $<0.02$ & Nil \\
$\mathrm{C}$ & $<0.01$ & $<0.05$ & $<0.02$ & $<0.02$ & Nil \\
$\mathrm{D}$ & $<0.01$ & $<0.05$ & $<0.02$ & $<0.02$ & Nil \\
E & $<0.01$ & $<0.05$ & $<0.02$ & $<0.02$ & Nil \\
\hline
\end{tabular}

A-D are Stagnant ponds with dirty water. E- pond with clean water.

\section{REFERENCES}

Adakole JA, Balogun JK. 2006. Pollution Status of an Urban Stream in Northern Nigeria through metal content of water sediment and fish. Nig. Jour of Fisheries, 23: $169-180$.

(APHA) American Public Health Association. 1981. Standard Methods for the Examination of Water and Wastewater, $15^{\text {th }}$ edn. APHA: Washington, DC, USA; 85-99, 773-779, 786-828.

AOAC. 1990, Official Methods of Analysis $\left(15^{\text {th }}\right.$ Edn). Association of Official Analytical Chemist: Washington D.C.

Boon JH, Huisman EA. 1996. Viral, bacterial and fungal diseases of Siluroidei, cultured for human consumption. Aquat. Living Resour., 9: 153-164.

Brenner KP, Rankin CC, Roybal YR Jr, Stelma GN, Scarpino PV, Dufour AP. 1993. New medium for the simultaneous detection of total coliforms and
Escherichia coli in water. Appl. Environ. Microbiol., 59: 3534-3544.

FDF (Federal Department of Fisheries), 2004. Fisheries Statistics of Nigeria. FDF.

Fawole MA, Oso BA. 2007. Laboratory Manual of Microbiology, Spectrum Books Ltd.: Ibadan. Nigeria; 127p.

Grant MA.1997. A new membrane filtration medium for simultaneous detection and enumeration of Escherichia coli and total coliform. Appl. Environ. Microbiol., 63: 3526-3530.

Klesius P. 1992. Carrier state of channel catfish infected with Edwardsiella ictaluri. J. Aquat. Anim. Health, 4: 227230.

Mqolomba TN, Plumb JA. 1992. Longevity of Edwardsiella ictaluri in the organs of experimentally infected channel catfish, Ictalurus punctatus. Aquaculture, 101: 16. 
Noga EJ. 2000. Fish Disease Diagnosis and Treatment. Iowa State University: Iowa, USA.

Nzeh CG, Udeze AO. 2011. Lactobacillus delbruekii infection of Clarias bidorsalis cultured in fish tanks in Ilorin, Kwara state-Nigeria. Agriculture and Biology Journal of North America. 2(2): 188-191.

Post G. 1987. Textbook of Fish Health Revised and Expanded. TFH publications: New Jersey, USA; 288.

Strauss M. 1985. Survival of excreted pathogens in excreta and feacal sludges. IRCWD News, 23: 4-9.

Talaro KP. 2005. The Gram-Negative Bacilli of medical importance. In Foundations in Microbiology (5th Edn). McGraw Hill; 605-628.
WHO, FAO. 1974. Recommended Intakes of Nutrients. Requirements different clinical forms: marasmus, kwashiorkor and kwashiorkor. J. of Energy, Protein, Vitamin, Calcium and Iron for Humans of all ages. Report of a joint FAO/WHO Expert group. Rome, p. 315 .

Willey JM, Sherwood LM, Wolverton CJ. 2008. Water purification and sanitary analysis. In Prescott, Harley, And Kleins's Microbiology (7th Edn). McGraw-Hill; 1050-1051.

WHO (World Health Organization). 1997. Guidelines for Drinking Water Quality: Surveillance and Control Communities Supplies (volume 3, $2^{\text {nd }}$ edn). WHO: Geneva, Switzerland. 